\title{
KONSTRUKSI MANHAJ AKADEMISI TERHADAP KITAB TAFSIR AL-FATIHAH KARYA MAHMUD YUNUS
}

\author{
Yulia Rahmi ${ }^{1}$ \\ ${ }^{1}$ Institut Agama Islam Negeri (LAIN) Bukittinggi, Indonesia, e-mail:yulia@iainbukittinggi.ac.id \\ (c) (1) (2) \\ (C)2020 by the authors. Submitted for possible open access publication under the terms and conditions of the Creative Commons \\ Attribution-ShareAlike 4.0 International License-(CC-BY-SA) (https://creativecommons.org/licenses/by-sa/4.0/) \\ do $D O I: \underline{\text { http://dx.doi.org/10.30983/it.v4i2.3407 }}$ \\ Diterima: 24 Agustus $2020 \quad$ Direvisi : 23 Desember $2020 \quad$ Diterbitkan: 31 Desember 2020
}

\begin{abstract}
This study explains Mahmud Yunus' interpretation construction from an academic perspective in the Tafsir Al-Fatibah book. This book appeared in the early 20th century, where interpretations in Indonesian or regional languages dominated interpretive works. So, uniquely, this book comes in Arabic script and different writing techniques and hermeneutics from the works that appeared in the era. The construction of this interpretation is studied with the literature method and philosophical, historical approach, by looking at the historical influence of Mahmud Yunus' social and scientific setting in producing the Tafsir Al-Fatihah, as well as studying the resulting interpretive building philosophically so that it displays the academic manhaj in this work. Mahmud Yunus' scientific career journey at several educational institutions in West Sumatra was a factor that encouraged him to compile a special interpretation book for intellectuals, where this work was compiled by presenting a wealth of information about Surah Al-Fatihah, presented with different systematic and more detailed writing techniques. With existing native interpretations.
\end{abstract}

Keywords: Mahmud Yunus; Tafsir method; Academician.

\begin{abstract}
Abstrak
Studi ini fokus menjelaskan tentang kontruksi penafsiran Mahmud Yunus dari perspektif akademisi dalam kitab Tafsir Al-Fatihah. Kitab ini muncul pada masa awal abad ke-20, dimana karya-karya tafsir yang didominasi oleh tafsir berbahasa Indonesia atau bahasa daerah Maka uniknya, kitab ini hadir dengan aksara dan bahasa Arab dengan teknik dan hermeneutika penulisan yang berbeda dengan karya-karya yang muncul pada eranya. Konstruksi tafsir ini dikaji dengan metode kepustakaan dan pendekatan historis filosofis, dengan melihat pengaruh historis setting sosial dan keilmuan Mahmud Yunus dalam menghasilkan kitab Tafsir AlFatihah, serta mengkaji secara filosofis bangunan penafsiran yang dihasilkan sehingga menampilkan manhaj akademisi pada karya ini. Perjalanan karir keilmuan Mahmud Yunus pada beberapa lembaga pendidikan di Sumatera Barat menjadi faktor yang mendorong beliau untuk menyusun kitab tafsir khusus bagi kalangan intelektual, dimana karya ini disusun dengan menampilkan kekayaan informasi tentang surat Al-Fatihah, disajikan dengan sistematika dan teknik penulisan yang lebih rinci berbeda dengan karya-karya tafsir pribumi yang ada.
\end{abstract}

Kata Kunci : Mahmud Yunus; Manhaj tafsir; Akademisi

\section{Latar Belakang}

Perkembangan tafsir di Indonesia pada periode pertama awal abad ke-20 hingga tahun 1960-an, masih diwarnai dengan model dan teknis penulisan yang masih sederhana dengan pembahasan terhadap ayat-ayat dengan penjelasan yang relatif singkat. Periode ini juga ditandai dengan adanya penerjemahan dan penafsiran dengan model penafsiran yang

${ }^{1}$ Islah Gusmian, Khazanah Tafsir Indonesia: dari Hermeneutika bingga Ideologi, Cetakan I (Yogyakarta: LKiS, 2013), 59-60. terpisah-pisah dan cenderung pada pembahasan pada surah-surah dan juz-juz tertentu, seperti alBurhaan Tafsir Juz 'Amma karya H.Abdul Karim Amrullah pada tahun 1922, Tafsir AlQur'an al-Karim, Yaasin karya Adnan Yahya Lubis tahun 1951, Kandungan Al-Fatihah karya Bahroem Rangkuti pada tahun 1960. ${ }^{1}$

Menurut Islah Gusmian pada periode ini, karya tafsir lebih didominasi oleh karya-karya 
yang membahas tentang surah Yasin dan tafsiran Juz 'Amma, dengan asumsi bahwa Yasin dan Juz 'Amma merupakan surah-surah Al-Qur'an yang populer dalam masyarakat Indonesia. Pada tradisi pembelajaran surau dan pesantren juz 'Amma merupakan bagian AlQur'an yang diajarkan paling awal, sedangkan surah yasin merupakan surah Al-Qur'an yang sering dibaca pada aktifitas dan ritual tertentu. ${ }^{2}$

Kitab Tafsir Al-Fatihah merupakan salah satu karya tafsir periode pertama awal abad 20 yang muncul pada tahun 1968, sesuai dengan namanya, fokus kajiannya adalah surat AlFatihah. Berbeda dengan corak kitab-kitab tafsir yang muncul pada periode pertama yang ditulis dengan model dan teknis yang sederhana, karya tafsir ini ditulis dengan model dan teknis penulisan yang lebih kompleks. Karya ini disajikan dengan bahasan yang lebih luas dan mendalam terhadap surat Al-Fatihah.

Hal yang menjadikan karya ini berbeda dengan karya tafsir lainnya adalah, penyajiannya dalam bahasa arab, sedangkan kitab tafsir nusantara lainnya lebih banyak menggunakan bahasa Indonesia, bahasa melayu, bahasa jawa atau bahasa daerah lainnya karena karya-karya tafsir ditujukan bagi masyarakat secara umum.

Untuk melihat deskripsi yang utuh terhadap manbaj ${ }^{3}$ Kitab Tafsir Al-Fatihah yang ditulis oleh Mahmud Yunus, perlu mengkaji kitab tafsir secara komprehensif dengan pendekatan historis filosofis. Pendekatan historis diterapkan dengan pertimbangan bahwa karya yang dihasilkan tidak bisa dilepaskan dari sosok Mahmud Yunus, pengalaman hidup, karir keilmuan serta setting sosial yang terjadi saat

${ }^{2}$ Gusmian, Khazanah Tafsir Indonesia, 61.

3 Manhaj dalam bahasa Indonesia berarti metode. Pada konteks ilmu Al-Qur'an dan Tafsir, Manhaj merupakan cara yang digunakan oleh mufassir untuk menjelaskan atau menafsirkan ayat-ayat Al-Qur'an berdasarkan kaedah-kaedah (aturan-aturan) yang telah dirumuskan dan diakui kebenarannya. Moh Quraish Shihab, Kaidah Tafsir, (Tangerang: Lentera Hati, 2015), 12.

${ }^{4}$ Surau merupakan sebutan untuk pusat pengajaran agama yang berpusat di masjid yang pada karya tersebut ditulis. Pendekatan filosofis digunakan untuk mengkaji bangunan manbaj akademisi yang digunakan Mahmud Yunus dalam menafsirkan surat Al-Fatihah, yang tidak bisa dilepaskan dari keaktifannya dalam berbagai kegiatan yang berhubungan dengan pendidikan dan disiplin keilmuan yang dimilikinya berpengaruh pada produk tafsir yang dihasilkannya. Sehingga karya tafsir AlFatihah beliau muncul berbeda dengan karya lain pada periode pertama tersebut.

\section{Riwayat Hidup Mahmud Yunus \& Perkembangan Penulisan Tafsir}

Bagian ini menguraikan riwayat hidup Mahmud Yunus secara ringkas; perkembangan latar kajian Al-Quran dan tafsir pada zamannya; serta dibahas juga atensi ulama asal Minangkabau itu pada bidang penafsiran $\mathrm{Al}$ Quran.

\section{Biografi Mahmud Yunus}

Mahmud Yunus lahir pada hari Sabtu tanggal 30 Ramadhan $1316 \mathrm{H}$ atau 10 Februari 1899 M di Sungayang Batusangkar Sumatera Barat. Mahmud Yunus dibesarkan di tengah keluarga dengan iklim keagamaan yang kental. Ayahnya bernama Yunus bin Incek seorang pengajar surau ${ }^{4}$ dan Imam nagari, sedangkan ibunya adalah Hafsah binti Imam Sami'un anak dari Angku Gadang M. Thahir Ali, pendiri dan pengasuh surau di Sungayang. ${ }^{5}$

Sejak kecil Mahmud Yunus telah mendapatkan pendidikan agama dari kakeknya M. Thahir Ali, mulai dari belajar mengaji hingga pelajaran dasar-dasar bahasa Arab. Pada tahun 1908 beliau memulai pendidikan formalnya pada Sekolah Desa. Ketika duduk di kelas 4,

umumnya terdapat pada setiap distrik nagari (kampung atau desa). Murni Djamal, Dr. H. Abdul Karim Amrullah, Pengarubnya dalam Gerakan Pembaruan Islam di Minangkabau Pada Awal Abad ke-20, Seri khusus INIS biografi sosialpolitik 2 (Jakarta: INIS, 2002), 1.

${ }^{5}$ Saiful Amin Ghofur, Mozaik Mufasir Al-Qur'an dari Klasik bingga Kontemporer (Yogyakarta: Kaukaba, 2013), 155. 
Mahmud Yunus pindah ke Sekolah Madrasah bernama Madras school di Surau Tanjung Pauh, yang didirikan oleh M. Thaib Umar, ${ }^{6}$ seorang tokoh Pembaharu di Minangkabau. Pada sekolah ini, Mahmud Yunus mendalami berbagai ilmu agama langsung di bawah asuhan M.Thaib Umar.

Pemikiran-pemikiran M. Thaib Umar banyak mempengaruhi pembentukan keilmuan Mahmud Yunus, melalui karya-karya gurunya tersebut Mahmud Yunus menyerap semangat pembaharuan dan pengembangan Islam. Kedekatannya dengan Thaib Umar juga yang membawanya ke forum besar Ulama Minangkabau pada tahun 1919 di Surau Jambatan Basi Padang Panjang. Ia datang ke forum tersebut sebagai wakil dari M. Thaib Umar.

Pada forum tersebut ia bersentuhan dengan pemikiran-pemikiran yang dikemukakan oleh sejumlah tokoh seperti Abdullah Ahmad, Abdul Karim Amrullah dan M. Djamil Djambek. ${ }^{8}$ Pada pertemuan itu pula dihasilkan kesepakatan pendirian PGAI (Persatuan Guru Agama Islam) yang merupakan organisasi yang mewadahi Ulama Minangkabau yang peduli pada pendidikan Islam, dimana Mahmud Yunus tergabung menjadi anggotanya. ${ }^{9}$

Pada tahun 1920 Mahmud Yunus dan beberapa orang lainnya membentuk persatuan

${ }^{6} \mathrm{M}$.Thaib Umar dikenal sebagai salah seorang perintis pergerakan pembaharuan Islam, terutama dalam sistem pendidikan di Minangkabau, beliau mendirikan Madras School pada tahun 1897, dan menjadikan sekolah tersebut sebagai lembaga pendidikan dengan dengan sistem pendidikan modern. Biltiser Bachtiar Manti et al., "Konsep Pendidikan Modern Mahmud Yunus dan Kontribusinya Bagi Lembaga Pendidikan Islam di Indonesia," Ta'dibuna: Jurnal Pendidikan Islam Vol. 5, no. 2 (Oktober 2016): 151., 164.

${ }^{7}$ Nurus Syarifah, "Tafsir Akademik Karya Mahmud Yunus: Corak Ilmiah, Sosial dan Intelektual dalam Tafsir Al-Qur'an Al-Karim," Jurnal At-Tibyan Jurnal Ilmu Al-Qur'an dan Tafsir 5, no. 1 (June 30, 2020), 107. lihat juga Tim Penulis Riwayat Hidup Mahmud Yunus, Riwayat Hidup Prof. Dr. Mahmud Yunus, 10 Februari 1988 - 16 Januari 1982, (Jakarta : Hidakarya Agung, t.th), 10. pelajar di Sungayang bernama Sumatera Thawalib, yang fokus pada banyak kegiatan, diantaranya menerbitkan Majalah al-Basyir dengan Mahmud Yunus sebagai pimpinan redaksinya. ${ }^{10}$ Majalah ini ditujukan sebagai media untuk menyuarakan semangat pembaharuan.

Interaksi yang semakin intens dengan gerakan pembaharuan, mendorongnya untuk menuntut ilmu ke Mesir. Pada tahun 1924 beliau berangkat ke Mesir mendalami ilmu Ushul Fiqh, Tafsir, Fiqh Hanafi dan berbagai ilmu lainnya, yang diselesaikan dalam waktu satu tahun dengan mendapatkan gelar Syahadah 'Alimiyah dari al-Azhar Kairo. Kemudian melanjutkan ke Madrasah Dar Al-Ulum yang diselesaikannya pada tahun 1930 dan mendapat ijazah diploma Guru. ${ }^{11}$

Setelah menyelesaikan studinya di Madrasah Dar Al-Ulum, Mahmud Yunus kembali ke Indonesia pada tahun 1931 dan mengabdikan ilmu-ilmunya untuk dunia pendidikan dan dunia akademis dengan aktif pada berbagai lembaga pendidikan dan menulis banyak buku hingga akhir hayatnya pada 16 Januari tahun 1982.

\section{Latar Sejarah Kajian Al-Qur'an dan Tafsir Era Mahmud Yunus}

Pengajaran Al-Qur'an dan Tafsir, pada awal masuknya Islam ke Indonesia belum dapat dideteksi melalui sumber tertulis. Hal ini sangat

\footnotetext{
${ }^{8}$ Rina Malta, "Pemikiran dan Karya-Karya Prof. Dr. H. Mahmud Yunus Tentang Pendidikan Islam (19201982)" (Padang, Universitas Andalas, 2011), 175

'Indah Muliati and Rini Rahman, "Teori Pedagogik Pendidikan Mahmud Yunus," Islam Transformatif: Journal of Islamic Studies 3, no. 2 (December 18, 2019): 169, 170

${ }^{10}$ Saiful Amin Ghofur, Mozaik Mufasir Al-Qur'an dari Klasik hingga Kontemporer (Yogyakarta: Kaukaba, 2013), 156

${ }^{11}$ Mahmud Yunus, "Pengantar Tafsir Al-Qur'an al-Karim," Pengantar Tafsir Al-Qur'an Al-Karim (blog), n.d., https:// tafsirmahmudyunus.blogspot.com. Lihat juga M. Anwar Syarifuddin and Jauhar Azizy, "Mahmud Yunus: Pelopor Pola Baru Penulisan Tafsir Al-Qur'ān Indonesia," Jurnal Ilmu Ushuluddin 2, no. 3 (June 2015)., 326
} 
dipengaruhi dengan metode transformasi keilmuan yang secara umum masih didominasi dengan teknik dan tradisi lisan.

Pada abad ke-16 ditemukan karya tafsir anonymous tentang surat al-Kahfi yang ditulis dengan bahasa melayu. Abad ini dinilai sebagai awal kemunculan karya tafsir tertulis di Indonesia yang dilanjutkan dengan kemunculan Tafsir Tarjuman Al-Mustafid karya Abdur Rauf Sinkili pada abad ke-17. ${ }^{12}$

Kebijakan politik Etis oleh pemerintah Belanda pada akhir abad ke-19 dalam bidang pendidikan, memberikan kesempatan bagi pribumi untuk mengecap pendidikan, walaupun kebijakan tersebut tidak terlepas dari kepentingan pemerintah Belanda sendiri. Dampak positif kebijakan tersebut adalah semakin banyak masyarakat Indonesia yang mengenal aksara dan dapat membaca. Kondisi ini tersebut secara tidak langsung telah memberikan ruang gerak yang cukup untuk intelektual nusantara mentransformasikan pemikiran-pemikiran keagamaan kepada masyarakat Indoresia dalam bentuk tertulis, termasuk dalam bidang tafsir.

Karya-karya pada bidang Al-Qur'an dan tafsir semakin marak hingga abad ke-20, ditandai dengan lahirnya berbagai karya tafsir nusantara, diantaranya adalah Tafsir Munir li Ma'alim Al-Tanæil karya Imam Muhammad Nawawi al-Bantani, Tafsir Al-Burban karya Haji Rasul, Tafsir Faid Ar-Rabman karya Kiyai Shaleh Darat, Tafsir Al-Ibriz karya Bisri Mustofa, AlIklīl fì Ma'añi Al-Tanzīl karya Misbah Zainul Mustafa.

12 Gusmian, Khazanah Tafsir Indonesia, 53.

13 Rosihon Anwar et al., "Menelusuri Pengaruh Pembaharuan di Mesir Terhadap Tradisi Tafsir di Nusantara: Kajian Terhadap Tafsir Qur'an Karim Karya Mahmud Yunus," Karya Tulis Ilmiah LP2M UIN SGD Bandung, 2020.

${ }^{14}$ Pada tafsir klasik penulisan tafsir belum dipisahkan, dimana ayat, terjemahan dan penjelasan diletakkan pada halaman yang sama, yang dibedakan hanya dengan jenis dan warna tulisan dan diletakkan dalam halaman yang sama tanpa pemisahan yang tegas.
Pembaharuan yang terjadi di dunia Islam, ditambah dengan kontak ulama nusantara dengan pemikiran pembaharu ikut mewarnai karya-karya tafsir nusantara abad ke-20. Semangat pembaharuan tidak hanya tertuang pada konten tafsir, yang sebelumnya lebih bercorak sufistik, berkembang pada pembahasan sosial kemasyarakatan, ${ }^{13}$ tetapi juga terlihat pada teknik penulisan yang mulai memisahkan antara ayat, terjemahan dan tafsiran pada tempat terpisah. ${ }^{14}$ Pada teknik penulisan tafsir yang biasa menggunakan bahasa lokal dengan aksara arab melayu (jam ), pegon, lontara dan cacarakan, ${ }^{15}$ mulai ditulis dengan menggunakan huruf latin berbahasa Indonesia. $^{16}$

Hingga periode pertama abad ke-20, penafsiran dengan menggunakan bahasa lokal banyak ditemukan pada karya-karya tafsir nusantara. Pasca sumpah pemuda pada tanggal 28 Oktober 1928, dimana bahasa Indonesia disepakati sebagai bahasa persatuan, aksara penulisan tafsirpun juga mulai ditulis dengan menggunakan aksara latin berbahasa Indonesia. Usaha tersebut dilakukan untuk mengakomodir kebutuhan masyarakat terhadap pemahaman Al-Qur'an. Di antara karya tafsir berbahasa Indonesia dengan huruf latin adalah Tafsir AlQur'an Al-Karim karya Mahmud Yunus, alFurqan; Tafsir Al-Qur'an karya Ahmad Hassan, Tafsir Al-Qur'an Al-Karim yang ditulis oleh tiga serangkai, A. Halim Hasan, Zainal Arifin Abbas, dan Abdurrahim Haitami. Tamsiyat Al-Muslimîn fî Tafsîr Kalâm Rabb Al-'Alamîn karya Ahmad Sanusi, Tafsir Al-Azhar karya Hamka dan berbagai karya lainnya.

Ahmad Zaiyadi, "Lokalitas Tafsir Nusantara: Dinamika Studi Al-Qur'an di Indonesia," Al-Bayan: Jurnal Ilmu AlQur'an dan Hadist 1, no. 1 (August 7, 2018): 12

15 Islah Gusmian, "Bahasa dan Aksara dalam Penulisan Tafsir Al-Qur'an di Indonesia Era Awal Abad 20 M," Mutawatir 5, no. 2 (September 28, 2016), 229

${ }^{16} \mathrm{Pada}$ umumnya masyarakat dan sebagian ulama masih menganggap bahwa upaya terjemahan dan penafsiran Al-Qur'an kedalam bahasa selain arab adalah aktifitas yang terlarang/haram. Syarifuddin and Azizy, "Mahmud Yunus," 327. 


\section{Atensi Mahmud Yunus pada Bidang Tafsir}

Karir keilmuan Mahmud Yunus telah dimulai sejak ia belajar di Surau kakeknya di Sungayang, dengan ikut menjadi pengajar untuk anak-anak yang baru belajar mengaji. Saat bersekolah di Madras School, Mahmud Yunus juga dipercaya oleh Gurunya M.Umar Thaib untuk mengajar dan bahkan menggantikan gurunya memimpin sekolah tersebut.

Setelah menyelesaikan pendidikan dan kembali dari Mesir, Mahmud Yunus aktif di berbagai lembaga pendidikan, antara lain $\mathrm{Al}$ Jami'ah Al-Islamiyyah di Sungayang, Sekolah Islam Tinggi (SIT) di Padang, Sekolah Menengah Islam (SMI) di Bukittinggi, dan IAIN Imam Bonjol di Padang.

Meskipun disibukkan dengan karir keilmuan, Mahmud Yunus masih menyempatkan diri untuk menuangkan ide-ide dan keilmuannya dalam bentuk karya tulis. Mahmud Yunus masuk dalam jajaran mufassir Indonesia yang produktif, tidak hanya di bidang tafsir tetapi juga memiliki keahlian pada bidangbidang keilmuan lainnya, yang dapat diketahui dari berbagai karya yang telah dihasilkannya. Selama hidupnya beliau telah menulis hingga 82 buku dalam berbagai disiplin keilmuan yang ditulis dengan bahasa Indonesia dan bahasa Arab.

Pada bidang Al-Qur'an dan tafsir, Mahmud Yunus telah mulai menulis tafsir pada tahun 1922. Pada saat itu, beliau telah mengajar pada lembaga pendidikan Madras School, yang kemudian berganti nama menjadi Al-Jami'ah Al-Islamiyyah di Sungayang.

Karya tafsir monumentalnya, Tafsir AlQur'an al-Karim, menjadi pionir penulisan tafsir lengkap 30 Juz berbahasa Indonesia dengan menggunakan aksara latin. Lewat karya tersebut beliau mendobrak pemikiran yang menganggap penterjemahan dan tafsir Al-Qur'an dalam

17 Rina Malta, "Pemikiran dan Karya-Karya Prof. Dr. H. Mahmud Yunus, 176-180

18 Biltiser Bachtiar Manti, "Konsep Pendidikan Modern Mahmud Yunus dan Kontribusinya Bagi aksara non arab adalah sesuatu yang haram. Melalui Karya ini juga, beliau mentransformasikan ide-ide pembaharuan pemikirannya terhadap Al-Qur'an kepada masyarakat luas.

Perhatian yang begitu besar pada bidang Al-Qur'an dan tafsir juga dapat dilihat dari karya-karya lain yang dihasilkan yaitu: Tafsir $\mathrm{Al}-$ Fatihah, Tafsir Ayat Akhlak, Juz Amma dan Terjemahannya, Tafsir Al-Quran Juz 1-10, Pelajaran Huruf Al-Quran, Kesimpulan Isi AlQuran, AlifBa Ta wa Juz. Amma, Mubadharaat AlIsrailiyyaat fi Al-Tafsir wa Al-Hadits, Kamus AlQuran I, Kamus Al-Quran II, Kamus Al-Quran (juz 1-30), dan Surat Yaasin dan Terjemahannya ${ }^{17}$

\section{Kitab Tafsir Al-Fatihah Karya Mahmud Yunus}

\section{Latar Belakang Penyusunan Kitab}

Mahmud Yunus memiliki kontribusi besar dalam bidang pendidikan di Indonesia. Beliau memperjuangkan masuknya kurikulum pelajaran Agama pada sekolah-sekolah umum. Ia tidak hanya berperan dalam menyusun kurikulum, akan tetapi juga dipercaya untuk menyusun sendiri buku-buku pegangan untuk bahan ajar. ${ }^{18}$ Kondisi ini juga sepertinya yang melatar belakangi penulisan kitab Tafsir AlFatihah.

Jejak karir akademik Mahmud Yunus sebagai tenaga pengajar pada berbagai ruang pendidikan menjadikan beliau paham pentingnya referensi tertulis sebagai bahan ajar dan pegangan bagi para mahasiswa. Terbatasnya referensi dan buku ajar dalam bidang tafsir yang dapat diakses oleh mahasiswa, sepertinya juga menjadi alasan ditulisnya karya ini.

Tafsir Al-Fatihah diterbitkan pada saat Mahmud Yunus menjadi Rektor IAIN Imam

Lembaga Pendidikan Islam di Indonesia," Ta'dibuna: Jurnal Pendidikan Islam 5, no. 2 (Oktober 2016): 158-59. 
Bonjol Padang yang merupakan Perguruan Tinggi Islam Negeri pertama di Sumatera Barat. IAIN Imam Bonjol Padang diresmikan pada tahun 1966, akan tetapi cikal bakalnya telah dimulai sejak didirikannya SIT pada tahun 1940. ${ }^{19}$ Karya-karya tafsir ulama nusantara pada periode ini lebih didominasi oleh karya-karya berbahasa Indonesia karena memang ditujukan untuk masyarakat Indonesia secara umum.

Pengajaran tafsir pada perguruan tinggi membutuhkan referensi yang lebih komprehensif dan mendalam karena akan dijadikan sebagai bahan diskusi dan penelitian. Kitab Tafsir Al-Fatibah merupakan salah satu karya Mahmud Yunus dalam bidang Al-Qur'an. Berbeda dengan karya tafsir monumentalnya, Tafsir Al-Qur'an Al-Karim ${ }^{20}$ yang menafsirkan Al-Qur'an secara ringkas dan mencakup 30 juz Al-Qur'an dan ditujukan untuk masyarakat secara umum, maka Tafsir Al-Fatihah yang disusun oleh Mahmud Yunus merupakan karya tafsir yang ditujukan untuk para akademisi, sebagaimana yang ditulis pada cover-nya طلبة

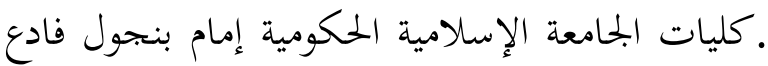
Pada awalnya, karya ini merupakan buku tafsir untuk mahasiswa Fakultas Syariah IAIN Imam Bonjol Padang. Kemudian karya yang terbit tahun 1968 ini, juga ditujukan untuk para penggiat tafsir secara umum.

${ }^{19}$ Sekolah Islam Tinggi merupakan perguruan tinggi Islam pertama di Minangkabau bahkan di Indonesia, yang didirikan oleh PGAI di Padang pada bulan Desember 1940. Mahmud Yunus dipercaya sebagai pimpinan pertamanya oleh PGAI. Sekolah Tinggi ini terdiri dari dua fakultas, yaitu : Fakultas Syari'ah dan Fakultas Pendidikan/Bahasa Arab. Sekolah ini berumur pendek, karena pada tahun 1942, Pemerintah Jepang yang saat itu telah menguasai kota Padang, tidak membolehkan adanya sekolah tinggi di daerah kekuasaannya Irhash A Shamad, "Tokoh Pendidikan Islam: Prof. Dr. H. Mahmud Yunus, (1899-1982)," Irhash's Cluster (blog), Desember 2008

${ }^{20}$ Karya Tafsir Al-Qur'an al-Karim ditulis pertama kali pada tahun 1922 yang dilkerjakan secara bertahap. Juz 1 sampai 3 ditulis oleh Mahmud Yunus dengan aksara
Sistematika Kitab Tafsir Al-Fatihah

Mahmud Yunus tidak menuliskan muqaddimah pada karya tafsir ini, akan tetapi sebagai pembuka, Mahmud Yunus menampilkan pembahasan tentang ta'awur, disertai dengan berbagai penjelasan yang berhubungan dengan persoalan ta'awuz, dimulai dari ma'na mufradat dari beberapa kata yang dianggap penting untuk dijelaskan, maksud ayat secara ringkas, kemudian penafsiran ta'awuz sehubungan dengan kedudukannya sebagai pembuka dari kegiatan membaca Al-Qur'an. ${ }^{21}$

Sebelum masuk pada pembahasan ayatayat dari surat Al-Fatihah, Mahmud Yunus memberikan informasi-informasi terkait dengan surat Al-Fatihah, seperti sebab penamaan Al-Fatihah, nama-nama lain dari surat Al-Fatihah, serta informasi-informasi lainnya yang menjadi bahasan atau perdebatan para ulama tentang surat Al-Fatihah. ${ }^{22}$

Pada setiap peralihan pembahasan, Mahmud Yunus mencantumkan subtitle pembahasannya. Pada penutup tafsirnya, Mahmud Yunus menampilkan juga bahasan tentang bahasan membaca Amin setelah surat Al-Fatihah. Selain itu dilengkapi juga dengan pembahasan tentang hukum membaca AlFatihah dalam shalat dan kedudukan bacaan $\mathrm{Al}$ Fatihah untuk makmum berdasarkan kacamata figh. ${ }^{23}$ Pada akhir karya tafsir ini, Mahmud

arab melayu, sedangkan juz ke-4 ditulis oleh Ilyas Muhammad Ali di bawah bimbingan Mahmud Yunus. Pada tahun 1935 penulisan tafsir dilanjutkan oleh M.Kasim Bakry sampai juz 18. 12 juz lainnya diselesaikan oleh Mahmud Yunus hingga tahun 1938. Tafsir ini telah mengalami 23 kali cetak ulang dan dialih aksarakan ke aksara latin. Nor Huda, Islam Nusantara: Sejarah Sosial Intelektual Islam di Indonesia, Cet. 1 (Yogjakarta: Ar-Ruzz Media, 2007), 357-358,. lihat juga Zulyadain Zulyadain, "Kerangka Paradigmatik Tafsir Alqur'an Alkarim Karya Mahmud Yunus," Al-A'raf: Jurnal Pemikiran Islam dan Filsafat 15, no. 1 (June 30, 2018), 135-137

${ }^{21}$ Mahmud Yunus, Tafsir Al-Fatihah (Padang Panjang: Sa'adyah Putra, 1968), 3-6

22 Mahmud Yunus, Tafsir Al-Fatihah, 7-8

${ }^{23}$ Mahmud Yunus, Tafsir Al-Fatibah, 47-56 
Yunus juga memuat daftar ralat untuk kata-kata yang terdapat kekeliruan penulisannya. ${ }^{24}$

\section{Teknik Penulisan Kitab Tafsir Al-Fatihah}

Aspek teknik penulisan kitab tafsir menggambarkan kerangka teknis yang digunakan Mahmud Yunus dalam menyusun kitab tafsir Al-Fatihah.

Pada Kitab Tafsir Al-Fatihah karya Mahmud Yunus dapat dirumuskan kerangka teknis penyusunan kitab sebagai berikut : Pertama, sistematika penyajian tafsir dengan mengkombinasikan penyajian secara runtut dan tematik. Sistematika penyajian tafsir terbagi kepada sistematika penyajian runtut dan sistematika penyajian tematik. Sistematika penyajian runtut adalah model penyajian yang berpedoman pada urutan surat yang ada pada mushaf standar atau berdasarkan kepada urutan turunnya ayat Al-Qur'an, sedangkan sistematika penyajian tematik adalah sistematika penyusunan kitab tafsir berdasarkan tema tertentu atau pada ayat, surat dan juz tertentu yang menjadi acuan mufassir dalam menggali makna ayat-ayat Al-Qur'an. ${ }^{25}$

Karya tafsir Al-Fatihah karya Mahmud Yunus, dari segi penyajian merupakan karya tafsir yang disajikan dengan model sistematika penyajian tematik, dengan membahas dan menafsirkan ayat Al-Fatihah saja sebagai fokus kajiannya. Tafsiran disajikan sesuai dengan urutan ayat, dari ayat pertama surat Al-Fatihah hingga ayat terakhir.

Kedua, bentuk penyajian secara rinci. Penafsiran berdasarkan bentuk penyajiannya dapat dibagi kepada dua bentuk, yaitu kajian secara global dan kajian secara rinci. ${ }^{26}$ Penafsiran Mahmud Yunus terhadap surat AlFatihah ditampilkan secara rinci dengan sistematika penafsiran setiap ayat dimulai dengan penjelasan mufradat, kemudian makna secara global, dilanjutkan dengan penafsiran secara rinci terhadap ayat-ayat dalam surat AlFatihah dengan menampilkan uraian-uraian secara mendalam dan komprehensif.

Pembahasan terhadap setiap ayat diperkaya dengan menampilkan penjelasan dari ayat atau hadis lain untuk menafsirkannya, selain itu juga dibahas berbagai pendapat ulama sehubungan dengan redaksi ayat yang ditafsirkan.

Ketiga, bentuk penulisan dan sumber Rujukan. Mekanisme penulisan yang digunakan oleh Mahmud Yunus, yang berhubungan dengan teknis dalam penyusunan karya tafsirnya, belum disajikan sesuai kaedah penulisan ilmiah modern yang mensyaratkan adanya footnote, endnote maupun bodynote dalam menjelaskan literatur yang dirujuk. Bentuk penyajian ilmah dari kitab ini dapat dilihat dari penyajian yang telah tersistematis dengan memberikan batasan yang jelas antara ayat, penjelasan mufradat hingga penafsiran secara rinci.

Pada beberapa penjelasan dalam kitab tafsirnya Mahmud Yunus menyebutkan namanama ulama yang dirujuk pendapatnya. Sebagaimana yang dapat dilihat ketika Mahmud Yunus mengutip pendapat Ibnu Katsir, ketika memberikan pendapat terhadap riwayat-riwayat yang menjelaskan makna المستقيم,27 Mahmud Syaltut ketika menjelaskan tentang makna المنعم atau Muhammad Abduh ketika menjelaskan 28 makna serta nama-nama lainnya. Hal ini dapat menunjukkan sisi ilmiah dari karya tafsir ini dalam progress konteks masa awal abad 20 hingga tahun 1960-an.

\section{Metode Kitab Tafsir Al-Fatibah}

Manhaj akademisi pada karya Tafsir AlFatihah ini tergambar dari aspek-aspek sebagai berikut: Pertama, Penggunaan Bahasa Arab sebagai bahasa pengantar
${ }^{24}$ Mahmud Yunus, Tafsir Al-Fatihah, 57-58

${ }^{25}$ Ishlah Gusmian, Khazanah Tafsir, 123

${ }^{26}$ Islah Gusmian, Khazanah Tafsir, 153
${ }^{27}$ Mahmud Yunus, Tafsir Al-Fatihah, 34
${ }^{28}$ Mahmud Yunus, Tafsir Al-Fatihah, 42
${ }^{29}$ Mahmud Yunus, Tafsir Al-Fatihah, 43

Konstruksi Manhaj Akademisi....... 
Penggunaan bahasa Arab sebagai bahasa pengantar pada tafsir Al-Fatihah, selain karena karya ini ditujukan bagi kalangan akademisi, juga terkait erat dengan ide-ide pembaharuannya tentang kurikulum pendidikan agama di Indonesia. Beliau memandang pentingnya bahasa arab sebagai media untuk mendalami ajaran-ajaran Islam yang didominasi oleh referensi berbahasa Arab. Penyajian kitab tafsir ini dengan bahasa arab ditujukan untuk mengasah kemampuan para akademisi dalam memahami literatur berbahasa arab.

Selain itu penggunaan bahasa arab sebagai bahasa pengantar menjadikan kitab ini memiliki skop pembaca yang lebih luas, tidak hanya akademisi nusantara, akan tetapi memberi peluang dapat dibaca oleh akademisi di tingkat internasional.

Kedua, penafsiran ayat dengan metode tablili (analitis) dengan mengkombinasikan berbagai corak penafsiran. Penafsiran terhadap surat Al-Fatihah dimulai dengan penjelasan mufradat, makna secara global dari ayat yang ditafsirkan, dilanjutkan dengan penjelasan secara analitis dengan mengeksplorasi segala hal yang terkait dengan ayat dari sudut pandang lughawi, fiqh, sosial kemasyarakatan maupun filsafat.

Kajian terhadap surat Al-Fatihah tidak hanya terfokus pada penjelasan redaksi ayat, akan tetapi juga menyertakan bahasan seputar konteks ayat. Misalnya ketika membahas tentang kata الحم, Mahmud Yunus membahasnya dalam perspektif lughawi, dan memperkaya bahasannya dengan menambahkan perbedaan kata tersebut dengan kata المدح dan Pada penjelasannya diungkapkan bahwa المدالحد dan dalah dua kata yang bermakna sama yaitu الثناء و النداء على lebih umum yang mencakup pujian atau syukur terhadap yang terlihat seperti harta, kerupawanan dan fisik disebutkan atau pun tidak. Kata الشكر merupakan pujian secara khusus dengan perantaraan hati, lidah maupun anggota tubuh. sedangkan dengan lidah saja yang merupakan bagian dari Penjelasan tersebut diperkuat dengan atsar berikut :

$$
\text { الحمد رأس الشكر , ما شكر الله عبد لمج يحمده : }
$$

Pada penggalan lanjutan tafsiran terhadap ayat, Mahmud Yunus mengkaji potongan ayat dengan penjelasan dengan perspektif adabul ijtima’i (sosial kemasyarakatan).

Sebagai tafsir dengan metode tablili, pembahasan yang disajikan pada tafsir AlFatihah ini kaya dengan berbagai informasi yang terkait dengan redaksi ayat yang dijelaskan secara detail. seperti pada pembahasan ayat .اهدنا الصراط المستقيم Mahmud Yunus tidak hanya menampilkan bahasan tentang tafsiran dari الصراط المستقيم, beliau juga mengkaji secara mendalam tentang makna dan macam-macam hidayah, pengaruh hidayah terhadap individu hingga 3 kelompok yang disebutkan dalam surat Al-Fatihah terkait hidayah tersebut. ${ }^{31}$ Setiap penjelasan diletakkan pada tempat khusus yang ditandai dengan subjudul masingmasing.

Kekayaan informasi yang disajikan dengan berbagai corak penafsiran, menjadi bahan diskusi yang melibatkan berbagai sisi keilmuan bagi pembacanya.

\section{Nuansa Tafsir Fiqh}

Tafsir Al-Fatihah ini, lebih didominasi corak / nuansa kajian hukum/fiqh pada setiap tafsirannya. Hal ini dapat dilihat dari penyajian persoalan-persoalan fiqh pada surat Al-Fatihah, dengan menampilkan perbedaan pendapat dengan mengutip pendapat-pendapat mazhab 
pada persoalan fiqh. Pemilihan corak fiqh sangat terkait erat dengan tujuan penulisan kitab tafsir ini sebagai referensi bagi mahasiswa pada Fakultas syari'ah.

Sebagaimana pada ayat pertama tentang

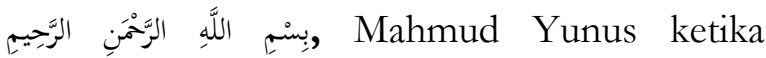
membahas ayat tersebut, beliau tidak hanya mengemukakan maksud dari ayat tersebut akan tetapi juga membahas penulisan lafaz بِ bukan dengan بuسِ menggunakan alif, ${ }^{32}$ membahas lafaz rahman dan rahim dan menghubungkannya dengan kata rahmah.

Pada ayat ini juga dibahas tentang perbedaan pendapat tentang apakah bismillah masuk bagian Al-Fatihah atau bukan, dan hukum membaca bismillah dalam shalat dengan menampilkan pendapat 5 mazhab fiqh, ${ }^{33}$ kemudian memberikan komentar terhadap dalil-dalil yang dikemukakan oleh para ulama tersebut.

\section{Pembahasan terhadap Ayat dengan Pendekatan Interteks}

Pendekatan interteks pada konteks ini merupakan penafsiran yang menjadikan teksteks lain sebagai acuan dalam memahami suatu ayat. Teks lain dapat berupa penafsiran lain yang telah ada sebelumnya atau pun teks dalam bentuk penjelasan-penjelasan yang mendukung penafsiran yang berasal dari riwayat atau pendapat para ulama dalam bahasannya. ${ }^{34}$

Bentuk interteks penafsiran Mahmud Yunus juga dapat ditelisik dari penafsiran yang mengacu pada teks lain berupa ayat-ayat lain atau informasi dari teks hadis atau atsar yang menjelaskan tentang maksud ayat. Selain itu Mahmud Yunus mengacu kepada pendapat ulama lain sebagai interteks untuk penafsirannya.

32 Mahmud Yunus, Tafsir Al-Fatihah, 10

${ }^{33}$ Mahmud Yunus, Tafsir Al-Fatihah, 9-18

34 Interteks dapat dibagi kepada dua bentuk, yaitu teks-teks lain yang ada di dalam teks diposisikan sebagai pedoman dalam proses tafsir, kedua, teks-teks di dalam teks tersebut diposisikan sebagai pembanding atau
Seperti halnya ketika menjelaskan tentang makna dari الصِّراطَ الْمُسْتَقِقِيمَ:

$$
\begin{aligned}
& \text { فيما رواه أحمد و الترمذى من رواية الحارث الأعور } \\
& \text { عن على مرفوعا وهو حبل الله المتين وهو الذكر } \\
& \text { الحكيم وهو صراط المستقيم... وقيل هو الإسل } \\
& \text { ام، و قيل بحاهد : اهْدِنَا الصِّرَاطَ الْهُسنتَِِيَمَ قال : } \\
& \text { الحق... }
\end{aligned}
$$

Penjelasan tentang الصِّراطَ الْمُسْتَقِيََ, dijelaskan dengan bantuan teks lain dari hadis yang diriwayatkan oleh Ahmad dan Tirmidzi, bahwa yang dimaksud adalah Islam atau kebenaran.

\section{Memberikan Analisa terhadap Persoalan Khilafiyah}

Pada penafsiran ayat yang menyajikan khilafiyah dalam persoalan fiqh, Mahmud Yunus mengulas pendapat-pendapat yang berbeda dengan menampilkan argumen masing-masing, kemudian memberikan pendapat pribadi terhadap persoalan yang dibahas.

Seperti halnya ketika membahas perbedaan pendapat terhadap hukum membaca basmalah dalam shalat, Mahmud Yunus mengemukan perbedaan pendapat para ulama, kemudian mengemukakan argumennya.
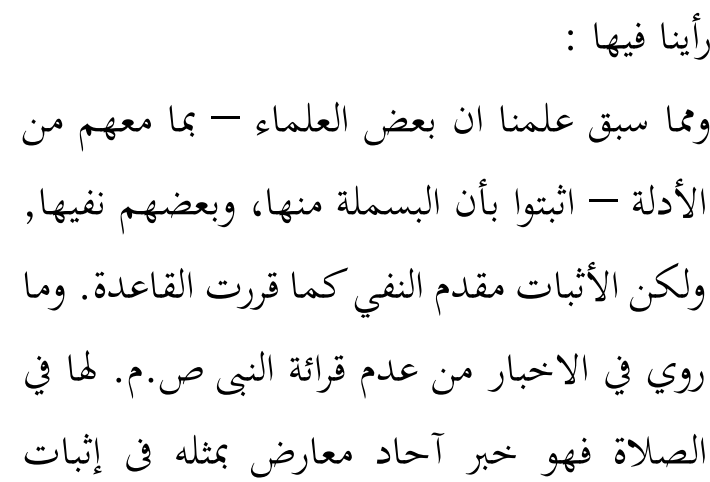

bahkan sebagai objek kritik untuk memberikan pembacaan baru, yang menurutnya lebih sesuai dengan dasar dan prinsip epistemologi, Islah Gusmian, Khazanah Tafsir, 211

${ }^{35}$ Mahmud Yunus, Tafsir Al-Fatihah, 34 


$$
\begin{aligned}
& \text { قراءقا وبما هو أقوى منه من تواتر كتابتها، ويحتمل } \\
& \text { ان يكون سببه عدم سماع الراوي لها، ففهم أنزل } \\
& \text { الله القرآن هدى و اماما وقدوة لنا. فافتتاحه بمثل } \\
& \text { هذه الكلمة ارشاد لنا بأن نفتتح اعمالنا بها، ليس لـأس } \\
& \text { معناه ان نفتتح أعمالنا باسم من اسماء الله تعالى } \\
& \text { بأن نذكره على سبيل التبرك او الاستعانة به بل أن } \\
& \text { نقول هذه العبارة "بسم الله الرحمن الرحيم" فإها } \\
& \text { مطلوبة لذاتما. }
\end{aligned}
$$

Berdasarkan gambaran dari Kitab Tafsir Al-Fatihah karya Mahmud Yunus tersebut, dapat dipahami bahwa, penafsiran yang dilakukan oleh Mahmud Yunus dengan mengemukakan berbagai hal yang terkait dengan ayat-ayat dari surat Al-Fatihah merupakan hasil dari pembacaan dan pengkajiannya dari berbagai sumber tafsir, yang kemudian ditulis dengan menggunakan bahasanya sendiri.

Satu hal yang menunjukkan keunggulan karya ini adalah kekayaan informasi yang disajikan Mahmud Yunus dalam membahas suatu pokok bahasan dalam tafsirnya. Mahmud Yunus menyertakan berbagai sudut pandang ayat walaupun dominasi fiqh lebih dominan dibandingkan dengan sudut pandang yang lain.

Pada karya tafsir ini, Mahmud Yunus tidak menyertakan sumber kutipan dan juga sumber rujukannya, baik dalam bentuk catatan kaki atau pun sumber referensi. Akan tetapi beliau menyebutkan rujukannya dengan menyebutkan nama ulama yang dirujuk pendapatnya sebagai bagian dari penjelasan pada tafsir tersebut.

Sebagai produk tafsir periode awal yang didominasi oleh penafsiran secara ringkas, bentuk penyajian tafsir seperti ini telah tampil dengan nuansa yang berbeda dengan bahasan yang lebih rinci dan sistematis, ditambah lagi dengan penggunaan bahasa Arab sebagai bahasa keaksaraan yang dipilih Mahmud Yunus menciptakan nuansa ilmiah dan akademis dibandingkan dengan produk-produk tafsir yang muncul pada periode awal tersebut.

\section{Kesimpulan}

Kontruksi Manhaj Akademisi dari Kitab Tafsir Al-Fatihah karya Mahmud Yunus, terlihat pada sistematika, teknik dan metode penafsiran yang ditampilkan pada karya ini. Sistematika penyajian yang dimulai dengan penjelasan seputar surat Al-Fatihah, diikuti dengan pembahasan masing-masing ayat dan dilengkapi juga dengan daftar ralat. Penjelasan tidak hanya terfokus pada redaksi tapi juga membahas konteks ayat secara detail.

Sebagai karya tafsir yang ditujukan untuk kalangan akademis, tidak mengherankan jika tafsir ini ditulis dengan bahasa dan kajian-kajian yang akademis juga. Dari segi bahasa karya tafsir ini ditulis dengan bahasa Arab, sedangkan bahasan-bahasan yang ditampilkan sangat kaya dengan informasi dan bahkan perbedaan pendapat ulama sebagai bahan untuk diskusi bagi para akademisi.

Karya tafsir ini dari segi materi dan penyajiannya banyak dipengaruhi oleh rujukan atau bahan bacaan yang bersumber dari karyakarya tafsir klasik hingga karya tafsir abad ke-20 yang telah ada sebelumnya. Akan tetapi dari segi sistematika, teknik penyusunan dan metode penulisan kitab tafsir Al-Fatihah ini terlihat lebih progressif dibandingkan karya-karya yang muncul pada masa tersebut.

\section{Daftar Kepustakaan}

Anwar, Rosihon, Asep Abdul Muhyi, Irma Riyani, and Muhammad Solahuddin. "Menelusuri Pengaruh Pembaharuan di Mesir Terhadap Tradisi Tafsir di Nusantara: Kajian terhadap Tafsir Qur'an Karim Karya Mahmud Yunus." Karya Tulis Ilmiah LP2M UIN SGD Bandung, 2020.

${ }^{36}$ Mahmud Yunus, Tafsir Al-Fatihah, 18-19 
Djamal, Murni. Dr. H. Abdul Karim Amrullah, Pengarubnya dalam Gerakan Pembaruan Islam di Minangkabau pada Awal Abad ke20. Seri khusus INIS biografi sosialpolitik 2. Jakarta: INIS, 2002.

Ghofur, Saiful Amin. Mozaik Mufasir Al-Qur'an dari Klasik bingga Kontemporer. Yogyakarta: Kaukaba, 2013.

Gusmian, Islah. "Bahasa dan Aksara dalam Penulisan Tafsir Al-Qur'an di Indonesia Era Awal Abad 20 M." Mutawatir 5, no. 2 (September 28, 2016): 223.

- Khazanah Tafsir Indonesia: dari Hermeneutika hingga Ideologi. Cetakan I. Yogyakarta: LKiS, 2013.

-. "Tafsir Al-Qur'an di Indonesia; Sejarah dan Dinamika." Jurnal Nun 1, no. 1 (2015).

Huda, Nor. Islam Nusantara: Sejarah Sosial Intelektual Islam di Indonesia. Cet. 1. Yogjakarta: Ar-Ruzz Media, 2007.

Malta, Rina. "Pemikiran dan Karya-Karya Prof. Dr. H. Mahmud Yunus tentang Pendidikan Islam (1920-1982)." Universitas Andalas, 2011. http://scholar.unand.ac.id/id/eprint/8 881.

Manti, Biltiser Bachtiar, Adian Husaini, Endin Mujahidin, and Didin Hafidhuddin. "Konsep Pendidikan Modern Mahmud Yunus dan Kontribusinya Bagi Lembaga Pendidikan Islam di Indonesia." Ta'dibuna: Jurnal Pendidikan Islam 5, no. 2 (Oktober 2016): 151.

Muliati, Indah, and Rini Rahman. "Teori Pedagogik Pendidikan Mahmud Yunus." Islam Transformatif: Journal of Islamic Studies 3, no. 2 (December 18, 2019): 169.
Shamad, Irhash A. "Tokoh Pendidikan Islam: Prof. Dr. H. Mahmud Yunus, (18991982)." Irbash's Cluster (blog), Desember 2008.

http://www.irhash.com/2008/12/prof -dr-h-mahmud-yunus-dan-

perkembangan.html.

Shihab, Moh Quraish. Kaidah Tafsir: Syarat, Ketentuan, dan Aturan Yang Patut Anda Ketabui dalam Memahami Ayat-Ayat AlQur'an: Dilengkapi Penjelasan Kritis Tentang Hermeneutika dalam Penafsiran AlQur'an. III. Tangerang: Lentera Hati, 2015.

Syarifah, Nurus. "Tafisr Akademik Karya Mahmud Yunus; Corak Ilmiah, Sosial dan Intelektual." Jurnal At-Tibyan Jurnal Ilmu Al-Quran dan Tafsir 5, no. 1 (June 2020): 103-18.

Syarifuddin, M. Anwar, and Jauhar Azizy. "Mahmud Yunus: Pelopor Pola Baru Penulisan Tafsir Al-Qur'ān Indonesia." Urnal Ilmu Ushuluddin 2, no. 3 (June 2015).

Yunus, Mahmud. "Pengantar Tafsir Al-Qur'an al-Karim." Pengantar Tafsir Al-Qur'an alKarim (blog), n.d. https://tafsirmahmudyunus.blogspot.c om.

- Tafsir Al-Fatibah. Padang Panjang: Sa'adyah Putra, 1968.

Zaiyadi, Ahmad. "Lokalitas Tafsir Nusantara: Dinamika Studi Al-Qur'an di Indonesia." Al-Bayan: Jurnal Ilmu AlQur'an dan Hadist 1, no. 1 (August 7, 2018): 01-26.

Zulyadain, Zulyadain. "Kerangka Paragdimatik Tafsir Al-Qur'an Al-Karim Karya Mahmud Yunus." Al-A'raf: Jurnal Pemikiran Islam dan Filsafat 15, no. 1 (2018): 127. 